\title{
RESEARCH PAPER \\ Seasonal pattern of root growth in relation to shoot phenology and soil temperature in sweet cherry trees (Prunus avium): A preliminary study in central Chile
}

\author{
Claudia Bonomelli ${ }^{1}$, Carlos Bonilla ${ }^{2}$, Edouard Acuña ${ }^{1}$, and Pamela Artacho ${ }^{3}$ \\ ${ }^{1}$ Facultad de Agronomía e Ingeniería Forestal, Departamento de Fruticultura y Enología, Pontificia \\ Universidad Católica de Chile. Vicuña Mackenna 4860, Macul, Santiago, Chile. \\ ${ }^{2}$ Facultad de Ingeniería, Departamento de Ingeniería Hidráulica y Ambiental, Pontificia Universidad \\ Católica de Chile. Vicuña Mackenna 4860, Macul, Santiago, Chile. \\ ${ }^{3}$ Facultad de Agronomía e Ingeniería Forestal, Programa de Postgrado en Ciencias de la Agricultura, \\ Pontificia Universidad Católica de Chile. Vicuña Mackenna 4860, Macul, Santiago, Chile.
}

\begin{abstract}
C. Bonomelli, C. Bonilla, E. Acuña, and P. Artacho. 2012. Seasonal pattern of root growth in relation to shoot phenology and soil temperature in sweet cherry trees (Prunus avium): A preliminary study in central Chile. Cien. Inv. Agr. 39(1): 127-136. The period between flowering and harvest in the sweet cherry (Prunus avium L.) is shorter than most fruit trees; thus, competition for assimilate and nutrients occurs early in the season. To properly supply water and nutrients during this critical period, optimal growth and root development are necessary. To characterize the root growth pattern of cherry trees in relation to shoot growth and phenology, a study was conducted on a 'Bing' cherry orchard on Gisela 6 rootstock at fourth leaf, located in central Chile $\left(34^{\circ} 70^{\prime}\right.$ S, $70^{\circ} 43^{\prime}$ ' W). During the 2009-2010 season, the shoot length and fruit diameter were measured on eight trees, and the root length was quantified by installing rhizotrons on two trees. Additionally, a two-tone (black/white) plastic cover was placed in the row over one tree with a rhizotron to analyze the effects of the plastic cover on soil temperature and root growth. The results showed three peaks of root growth during the season. The first peak occurred 43 days after full bloom (DAFB), corresponding to the phenological stages of the fruit turning from green to straw color. This peak occurred at 326 accumulated degree days (ADD) in the soil and 212 ADD in the air. The second peak was observed after harvest at 97 DAFB, when the shoot growth had stopped, and the soil and air had accumulated 932 and 692 degree days, respectively. The third and last peak occurred at 167 DAFB, with 1887 ADD in the soil and 1361 ADD in the air. The plastic cover increased the average soil temperature by approximately $1^{\circ} \mathrm{C}$, thereby increasing the ADD by 105.2 units during the study period. However, this increase was not enough to affect the root growth pattern.
\end{abstract}

Key words: Accumulated degree days, root growth, root length, soil temperature, sweet cherry.

\section{Introduction}

The root system serves diverse functions, including anchorage and water and nutrient uptake. The

Received July 12, 2010. Accepted May 6, 2011. Corresponding author: cbonomel@uc.cl absorptive portion of the root system is associated with the fine lateral roots, which may be replaced several times per year and represent the most dynamic portion of the root system (Comas et al., 2002). There is no information about root growth patterns for many woody plants, including 
cherry trees (Prunus avium L.). This information is important for the optimization of soil and nutrient management. However, studies on root systems are scarce because most of the methods used are extremely time-consuming, tedious, and destructive, particularly in large perennial plants such as fruit trees. In general terms, there are five approaches for root growth studies, including whole tree excavation, root sampling methods, observation windows (rhizotrons), root activity measurements, and indirect methods (Black et al., 2010). The observation window technique studies the roots through large reinforced glass or plastic windows installed against a vertical soil profile in a trench. This method was first used by Sachs in 1873 and later evolved into root laboratories or simple underground boxes known as rhizotrons (Böhm, 1979). Rhizotrons are among the common methods of observing roots (Futsaether and Oxaal, 2002), and most current knowledge of roots and the rhizosphere still come from experiments with plants growing in rhizotrons and modified rhizotrons (Neuman et al., 2009). The main advantage of this type of system is that it allows a continuous study of the roots of the plants during a complete life cycle.

Root growth and development are controlled by genetic and environmental factors, such as temperature, water availability, nutrients, oxygen and the physical properties of the soil (Ang et al., 2009). Additionally, root growth is related to the growth of shoots and fruit during the season and to the interaction between the rootstock and the scion (Sitarek et al., 2005). For example, in peach trees (Prunus persica L.), low rates of fruit growth have been observed to coincide with the highest rates of root growth, while a rapid increase in the rate of fruit growth during stage III is associated with a low rate of root growth (Abrisqueta et al., 2008). Other authors have reported that the presence of fruit reduces the shoot length and the dry weight of the shoots and leaves in peach trees (Grossman and Dejong, 1995). This is extremely important because in Prunus species, the formation of fruit has priority over other organ sinks (Flore and Layne, 1999). Additionally, Honorato et al. (1990) demonstrated that the equilibrium between above- and below-ground components was fundamental to the productivity of vineyards. The most productive vineyards had the largest root volume and thus, the largest organic reserves and shoot growth. The least productive vineyards showed a restricted root and shoot growth and a lower level of organic reserves.

Among the soil factors that influence root growth, temperature is one of the most important due to its strong effect on nutrient uptake and plant growth (Baghour et al., 2003). In this context, one of the main benefits associated with the use of plastic mulches is a higher root zone temperature (Lamont, 2005), which has been effective in increasing the dry matter of roots in broccoli plants (Brassica oleracea L.) (Díaz-Pérez, 2009) and root growth and the accumulated dry matter of the shoots in black currants (Ribes nigrum L.) (Larsson and Jensen, 1996). However, this practice would be more useful in regions where low soil temperature is a limiting factor. Additionally, other cultural practices, such as grafting, also affect above- and below-ground plant relationships. Cherry rootstocks influence the performance of the scion, including fruit quality (Jiménez et al., 2004), tree growth and yield (Moreno et al., 2001), and floral and foliar nutrition (Neilsen and Kappel, 1996; Jiménez et al., 2007). Newly planted cherry orchards in Chile and worldwide have been mainly established in high densities, in which are necessary dwarfing rootstocks to reduce tree vigor. In these rootstock types, the critical stage when the fruits and shoots compete with the roots has not been established. Therefore, the objectives of this study were to quantify the relationship between the aerial and root growth of trees in a high-density cherry orchard and to determine the effects of ground cover on soil temperature and root growth rate. 


\section{Materials and methods}

\author{
Relationship between shoots, fruit and root \\ growth
}

The study was conducted in an experimental sweet cherry orchard, cv. 'Bing' on Gisela 6 rootstock, located in central Chile (34 $07^{\prime} 55^{\prime}$ ' $\mathrm{S}$ and $70^{\circ} 43^{\prime} 15^{\prime}$ ' $\mathrm{W})$. The climate in the area is warm temperate with a long dry season. The average monthly temperatures are approximately $19.5^{\circ} \mathrm{C}$ in the summer months (January and February) and $7.5^{\circ} \mathrm{C}$ in the winter (June and July). Precipitation is concentrated in the May-September period, and there are seven months (October to April) with an average monthly precipitation lower than $40 \mathrm{~mm}$ (Gastó et al. 2008). The soil is classified as Fluventic Haploxerolls, according to Soil Taxonomy-USDA, with a clay-loam texture, flat topography, moderate depth $(75-100 \mathrm{~cm})$ and good drainage (CIREN, 1996). The main chemical and physical characteristics are shown in Table 1.

Table 1. Physical and chemical soil properties in the study site $(0-30 \mathrm{~cm})$.

\begin{tabular}{lc}
\hline Property & Value \\
\hline Clay (\%) & 29.5 \\
Silt (\%) & 44.0 \\
Sand (\%) & 26.5 \\
Organic matter (\%) & 3.2 \\
$\mathrm{~N}\left(\mathrm{mg} \mathrm{kg}^{-1}\right)$ & 17 \\
$\mathrm{P}-$ Olsen $\left(\mathrm{mg} \mathrm{kg}^{-1}\right)$ & 32 \\
$\mathrm{~K}\left(\mathrm{mg} \mathrm{kg}^{-1}\right)$ & 161 \\
$\mathrm{Ca}\left(\mathrm{meq} \mathrm{L}^{-1}\right)$ & 12.5 \\
Electrical conductivity in suspension $\left(\mathrm{mS} \mathrm{cm}^{-1}\right)$ & 0.15 \\
pH in suspension & 7.27 \\
\hline
\end{tabular}

The orchard was established in August 2006, with a plant density of 889 plants ha $^{-1}(4.5 \times 2.5$ $\mathrm{m})$ on raised ridges ( $1.5 \mathrm{~m}$ wide $\mathrm{x} 0.2 \mathrm{~m}$ high). The trees were approximately trained to the Vogel Spindle system, and the Black Tartarian cultivar was used as pollinizer in a proportion of $11 \%$. Irrigation was applied through a double drip line system with $4 \mathrm{~L} \mathrm{~h}^{-1}$ emitters located every $0.9 \mathrm{~m}$ along the row.
To study the root growth, rhizotrons were installed in two representative trees (R1 and R2), at $0.5 \mathrm{~m}$ from the trunk. Rhizotrons are glass front observation boxes that allow root development along the transparent walls (Böhm, 1979). In this study, the rhizotrons were $1.2 \mathrm{~m}$ wide by $1.2 \mathrm{~m}$ long and 1.2 $\mathrm{m}$ deep, with a glass of $1.10 \mathrm{~m}$ wide, $1.15 \mathrm{~m}$ long and $8 \mathrm{~mm}$ thick. Additionally, the soil temperature and volumetric water content were measured every $15 \mathrm{~min}$ at $20 \mathrm{~cm}$ depth using an EC-TM sensor (Decagon Devices Inc., Washington, USA) that was connected to an EM50 data logger (Decagon Devices Inc., Washington, USA). The air temperature was recorded using a sensor located $1 \mathrm{~m}$ above the ground that was connected to a WatchDog 450 data logger (Spectrum Technologies Inc., Illinois, USA).

From September 2009 to May 2010, the length of the absorptive roots (white roots) was weekly quantified from digital images captured from the rhizotrons, following procedures outlined by Sotomayor et al. (2009). Using AutoCAD ${ }^{\circledR}$ 2007 (Autodesk Inc., California, USA), the extension of each white root in the glass was marked with digital lines, and the total length was recorded. White roots (youngest) were selected because they exhibit a considerably higher nutrient absorptive capacity and respiration rate than pigmented (brown) roots (Baldi et al., 2010; Volder et al., 2005). It is known that tree roots transit by visually identifiable stages during their lifetime. New roots are white and turn brown several weeks or months later. This color change has been associated with marked physiological changes resulting in differences in nutrient uptake, respiration rate and anatomy (Comas et al., 2000, Wells and Eissenstat, 2001; 2003). To characterize the growth of shoots and fruits during the season, eight trees were selected, including the trees with the rhizotrons. The growth of four apical shoots per tree were measured weekly, each one from representative branches. At the same time, the fruit growth was assessed by measuring the equatorial diameters in four fruits per tree using a digital caliper (Digimess, Buenos Aires, Argentina). 
Additionally, the tree growth and development were related to the air and soil temperature accumulation expressed as accumulation of degree days (ADD):

$$
\mathrm{ADD}=\sum_{i=1}^{n}(T z-T b)
$$

where $\mathrm{n}$ is the number of days after full bloom (DAFB) to reach each phenological event or until the end of the evaluated period, $\mathrm{Tz}$ is the average daily soil or air temperature, and $\mathrm{Tb}$ is the base temperature $\left(10^{\circ} \mathrm{C}\right)$. These calculations were performed for different soil depths and for trees with and without the plastic cover.

\section{Effect of plastic cover}

The effect of soil temperature on root growth was evaluated by placing a two-tone plastic cover (black on the surface in contact with the ground/white on the upper surface) in the row over five trees, including one tree with a rhizotron. The other tree with a rhizotron was left uncovered. The plastic cover was 60 microns thick and $8 \mathrm{~m}$ long by $1.4 \mathrm{~m}$ wide and was installed in the spring (early September, 2009). To complement the soil measurements from the rhizotrons, the soil temperature was recorded weekly at a $10-\mathrm{cm}$ depth using a solid digital thermometer (CHY, 505 RTD Thermometer, Taiwan) in five covered and uncovered trees. The effect of the plastic cover on the soil temperature was analyzed from November to January by repeated measures analysis of variance, and the means were compared using a Tukey-test in STATISTICA 7.0 software (Steel et al., 1997).

\section{Results and discussion}

Relationship between root, shoot, and fruit growth

During the season under study, the first bearing season, three peaks of root growth were recorded. The first peak of root growth coincided with the rapid vegetative and reproductive growth (Fig- ure 1) between 36 and 49 days after full bloom (DAFB) when the fruit color changed from green to straw-tone. During this period, the shoots grew at a rate of approximately $5 \mathrm{~cm}$ per week. Gil (1999) mentioned that the first period of root growth is short when the initial growth of shoots is vigorous. When the shoots are not vigorous, the first period of root growth is longer and there is an early initiation of the second period of root growth. At the beginning of the growing season, the competition for photosynthates between aerial and root components affects the peaks of white root growth; the first peak is lower than the second and third peaks, which was observed in this study (Figure 1). The vegetative growth started on October 21, two weeks after the emergence of the first white roots. This was evidence of early competition between the aerial and root parts of the tree during this period. On December 12, the shoot growth rates diminished, and shoot growth stopped approximately two weeks later. At the same time, white root production rapidly increased, peaking for the second time on January 11, 2010. Afterwards, white root production decreased again until March 10, when the roots resumed a growth rate that lead to the third peak on March 22, 2010. This pattern of root growth has also been observed by Abrisqueta et al. (2008) in peach trees. In their work, a first peak occurred early in the spring, followed by a second peak immediately after harvest. Additionally, a third peak was reported in October, just before the beginning of winter in the Northern Hemisphere. In contrast, the date of the first two peaks in our study differed from those described by Gratacós et al. (2008) for the same cultivar and rootstock in central Chile. They mentioned that root activity started in September, with the main peak in October and with a moderate growth for the rest of the season. Nevertheless, the pattern of root growth reported on Gisela 5 in that study is similar to that observed in the present study, with a first peak of root growth in late October, followed by the second and main peak between late December and early January, and the third peak in the second half of March 
(Gratacós et al., 2008). In this study, a decrease in production of new roots was observed in the last phase of fruit growth, reflecting a competition for resources between fruit and root (Figure 1). It is known that cherry productivity depends on the supply and storage of photosynthates, as well as on the ability to transport photosynthates to the reproductive structures (Flore and Layne, 1999, Ayala and Lang, 2004), and that these processes can modulate the competition level between aerial and root components.

\section{Relationship between root growth and accumulated degree days}

Accumulated degree days (ADD) have been used to study and to forecast flowering, harvest and other phenological events in fruit crops. For example, Alburquerque et al. (2008) mentioned that mid-season cherry cultivars are very similar regarding their ADD requirement from dormancy to $50 \%$ flowering. Other authors have used this parameter to develop predictive models to estimate the number of days between full bloom and harvest in Prunus species (Day et al., 2008). However, there is no known evidence linking ADD with peak root growth in cherry or other fruit trees. In this study, the first root growth peak occurred at 43 days after full bloom (DAFB), with 326 ADD in soil at $20 \mathrm{~cm}$ depth and 212 ADD in the air (Table 2). This peak coincided with the time of fruit color change, which is easily observed in the field. If these events are usually correlated for the variety/ rootstock and edaphoclimatic combinations, fruit color change could be used as an indicator to recognize the occurrence of the first maximum root growth. Hence, it is important to evaluate these observations under variable conditions, such as colder climatic conditions and vigorous rootstocks. The second maximum root growth took place at $97 \mathrm{DAFB}$, with $932 \mathrm{ADD}$ in the soil and 692 ADD in air, and the third and final root growth peak was observed at 167 DAFB, with 1887 ADD in the soil and 1361 ADD in the air. There was a high correlation between air and soil ADD at $20 \mathrm{~cm}$ depth $\left(\mathrm{R}^{2}=0.999\right)$. The soil and air ADD for other phenological events are presented in Table 2 .

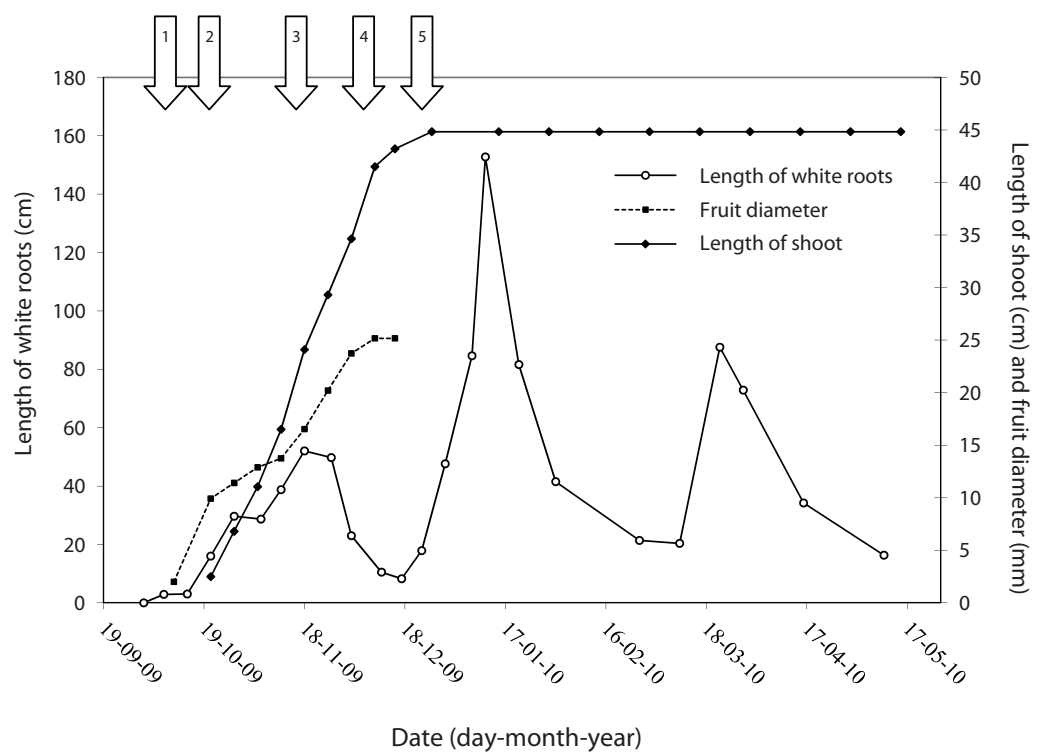

Figure 1. Root (0-90 cm soil depth), shoot and fruit growth of cherry cv. 'Bing' on Gisela 6 during the 2009-2010 growing season in central Chile. 1 = flowering, 2 = petal fall, 3 = fruit color change from green to straw, $4=$ fruit coloring, $5=$ harvest. 
Table 2. Relationship between cherry phenological stages and accumulated degree days in soil at a 20-cm depth and in air for trees without the plastic cover.

\begin{tabular}{|c|c|c|c|c|}
\hline $\begin{array}{l}\text { Date } \\
\text { (dd-mm-yr) }\end{array}$ & DAFB & Phenological stage & Soil ADD & Air ADD \\
\hline 06-10-2009 & 0 & Full Bloom & 0 & 0 \\
\hline $14-10-2009$ & 8 & Petal fall & 71 & 40 \\
\hline 11-11-2009 & 36 & Fruit color change from green to straw & 259 & 161 \\
\hline $18-11-2009$ & 43 & First root growth peak & 326 & 212 \\
\hline 24-11-2009 & 49 & Fruit coloring & 361 & 247 \\
\hline $18-12-2009$ & 73 & Harvest & 620 & 461 \\
\hline 26-12-2009 & 81 & Shoot growth end & 720 & 540 \\
\hline $11-01-2010$ & 97 & Second root peak & 932 & 692 \\
\hline 22-03-2010 & 167 & Third root peak & 1887 & 1361 \\
\hline
\end{tabular}

DAFB, days after full bloom; ADD, accumulated degree days (base temperature $=10^{\circ} \mathrm{C}$ ).

\section{Effect of plastic cover}

The temperatures from November to January at a $10-\mathrm{cm}$ and $20-\mathrm{cm}$ soil depth in trees with and without the plastic cover are shown in Figure 2. The average temperature at the $10-\mathrm{cm}$ depth during the period under study (13 measurements) was significantly higher in the soil with the cover than without the cover $\left(21.7^{\circ} \mathrm{C}\right.$ versus $20.9^{\circ} \mathrm{C}$, respectively; $\mathrm{F}_{1,6}=7.5, \mathrm{P}=0.03$ ). At the $20-\mathrm{cm}$ soil depth, a similar difference was observed, with average temperatures of $21.1^{\circ} \mathrm{C}$ and 20.2 ${ }^{\circ} \mathrm{C}$, respectively, for the soil with and without the cover. There was also a significant effect of time
$\left(\mathrm{F}_{12,72}=40.35, \mathrm{P} \leq 0.0001\right)$ showing an increasing trend towards the summer (Figure 2). The cover $\mathrm{x}$ time interaction was also significant $\left(\mathrm{F}_{12,72}\right.$ $=2.18, \mathrm{P}=0.02$ ), with soil temperatures without the cover initially higher than those for the soil with the cover. However, the opposite effect occurred from mid-November onwards. Higher soil temperatures at the $20-\mathrm{cm}$ depth with the plastic cover from November to January resulted in an increase of 105.2 degree days compared to the bare soil (Figure 2). Similar results have been reported by Ibarra et al. (2008) in cucumbers and by Díaz-Pérez (2009) in broccoli, when comparing temperatures between bare soil and a soil covered
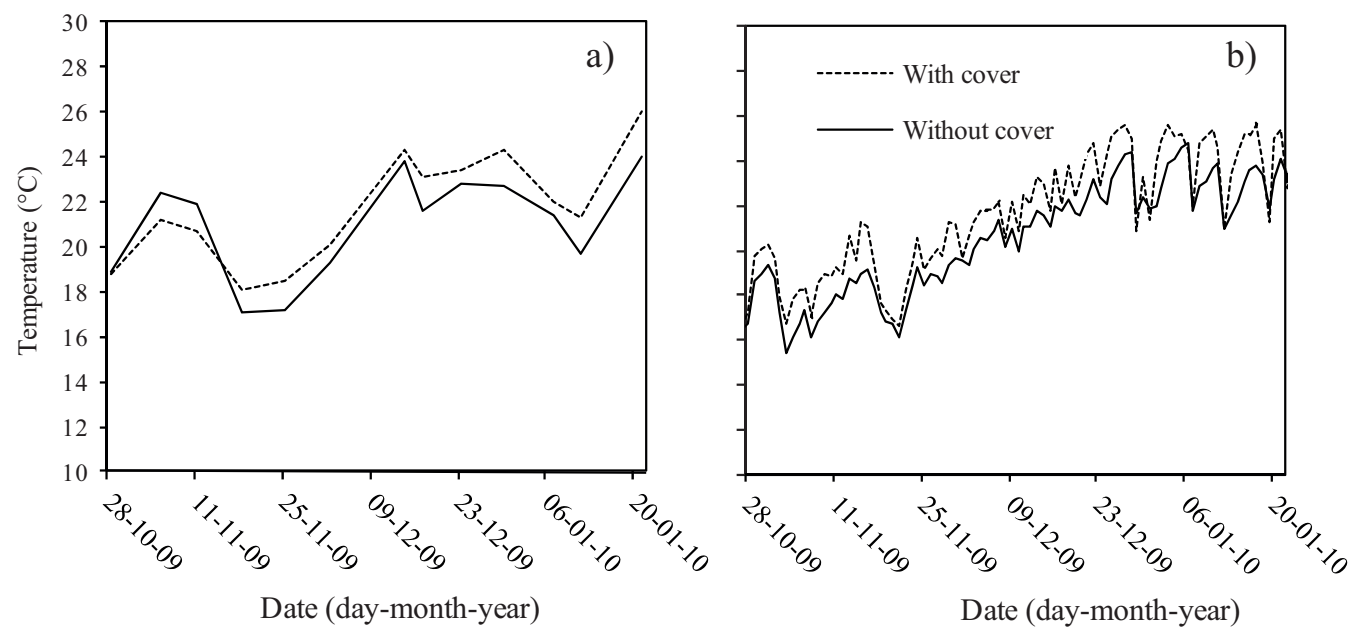

Figure 2. Effect of plastic cover on soil temperature at (a) $10 \mathrm{~cm}(\mathrm{n}=5)$ and (b) $20 \mathrm{~cm}$ depth. 


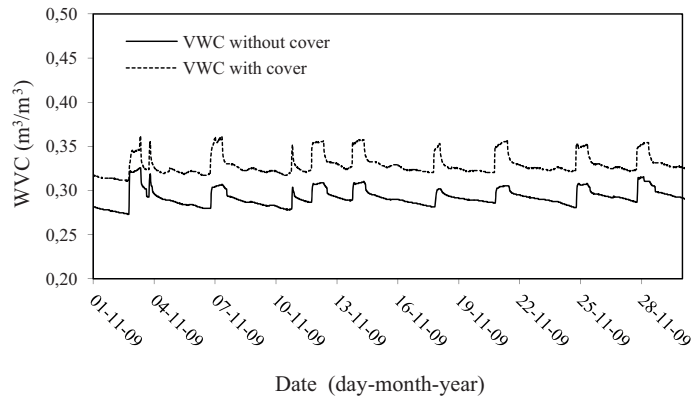

Figure 3. Effect of plastic cover on the volumetric water content (VWC) of soil at a $20-\mathrm{cm}$ depth during November 2009 .

by a bicolor plastic. Figure 3 shows the effect of the plastic cover on soil water content during November, the period with the highest competition between aerial and root activity. It was noted that the soil moisture content at a $20-\mathrm{cm}$ depth in soil with the plastic cover was higher than in bare soil. These results were consistent with other studies reporting a reduction of soil evaporation when a plastic cover was placed over soil (Anikwe et al., 2007, Larsson and Jensen, 1996).

In relation to root growth in soil with and without a plastic cover, the first peak occurred one week earlier in bare soil (November 18) than in soil with the plastic cover (November 26) (Figure 4). Interestingly, the second growth peak was on January 11, 2010, for both treatments, despite the fact that this second root flush began earlier in the soil without the plastic cover compared to the covered soil. Therefore, even though the plastic cover significantly increased the soil temperature for most of the season and consequently increased the accumulated degree days in the soil and the soil moisture in comparison with bare soil, the root growth pattern was not noticeably affected. The

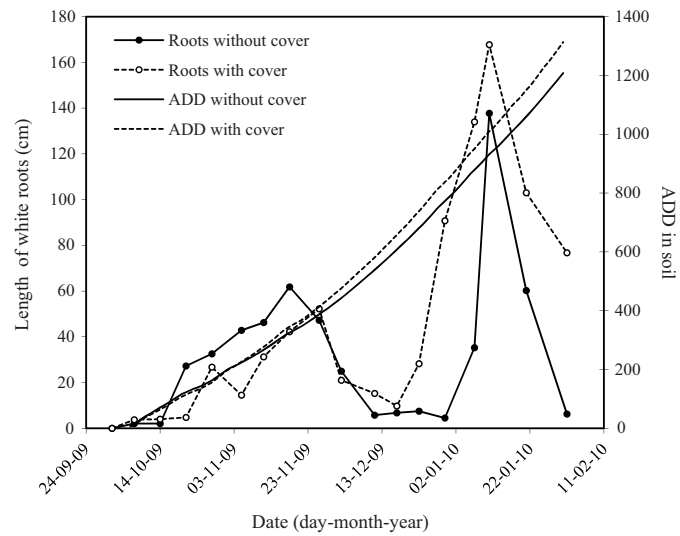

Figure 4. Effect of plastic cover on root growth (0-90 soil depth) and accumulated degree days (ADD) in soil at a 20cm depth.

root growth pattern was most likely not affected because the temperatures prevailing during the growing season in the soil were above the minimum requirements for root growth. Specifically, the soil temperature was always in a suitable range for root growth, that is, above $14{ }^{\circ} \mathrm{C}$ and below $28^{\circ} \mathrm{C}$. This might not be the case for other cherry growing regions, such as the northern United States and Europe. Furthermore, the use of clear plastic covers under central Chile growing conditions could generate excessively high soil temperatures that can have negative effects on root growth (Bonomelli et al., 2009).

\section{Acknowledgements}

The authors thank the Soil Analyses Laboratory of the Facultad de Agronomía e Ingeniería Forestal, Pontificia Universidad Católica de Chile (FAIF) for logistic support.

\section{Resumen}

C. Bonomelli, C. Bonilla, E. Acuña y P. Artacho. 2012. Patrón estacional de crecimiento radical en relación a la fenología aérea y temperatura de suelo en árboles de cerezo dulce (Prunus avium). Un estudio preliminar en Chile central. Cien. Inv. Agr. 39(1): 127-136. El periodo entre floración y cosecha en cerezo dulce (Prunus avium L.) es más corto que en la mayoría de los frutales, por lo que la competencia por fotoasimilados y nutrientes ocurre 
temprano en la estación. Para asegurar un suministro adecuado de agua y nutrientes durante este período crítico, se requiere un crecimiento y desarrollo radical óptimos. Para caracterizar el patrón de crecimiento radical en árboles de cerezo en relación al crecimiento y fenología de su parte aérea, se realizó un estudio en un huerto de cerezo 'Bing' sobre el portainjerto Gisela 6 en su cuarta hoja, ubicado en Chile central (34 $34^{\circ} 0^{\prime}$ S, $70^{\circ} 43^{\prime}$ O). Durante la estación 20092010, se midió el largo de brotes y diámetro de frutos en ocho árboles, y se cuantificó el largo de raíces blancas a través de la instalación de rizotrones en dos árboles. Adicionalmente, se instaló una cubierta plástica de dos tonos (negro/blanco) sobre la hilera en un árbol con un rizotrón para analizar su efecto sobre la temperatura de suelo y el crecimiento radical. Se observaron tres picos de crecimiento radical durante la estación. El primero ocurrió 43 días después de plena flor (DDPF), correspondiendo al estado fenológico de cambio de color del fruto desde paja a coloreado. Este pico ocurrió con 326 días grados acumulados (DGA) en el suelo y con 212 DGA en el aire. El segundo pico se observó después de la cosecha (97 DDPF), cuando el crecimiento de brotes se había detenido y se habían acumulado 932 y 692 días grados en el suelo y aire, respectivamente. El tercer y último pico se produjo 167 DDPF, con 1887 DGA en el suelo y 1361 DGA en el aire. La cubierta plástica aumentó la temperatura promedio del suelo en aproximadamente $1{ }^{\circ} \mathrm{C}$, aumentando los DGA en 105,2 unidades durante el período estudiado. Sin embargo, esto no fue suficiente para modificar el patrón de crecimiento radical.

Palabras clave: Cerezo dulce, crecimiento radical, días grados acumulados, largo de raíces, temperatura de suelo.

\section{References}

Abrisqueta, J.M., O. Mounzer, S. Alvarez, W. Conejero, Y. García-Orellana, L.M. Tapia, J. Vera, I. Abrisqueta, and M.C. Ruiz-Sánchez. 2008. Root dynamics of peach trees submitted to partial rootzone drying and continuous deficit irrigation. Agricultural Water Management 95: 959-967.

Alburquerque, N., F. García, A. Carrillo, and L. Burgos. 2008. Chilling and heat requirements of sweet cherry cultivars and the relationship between altitude and the probability of satisfying the chill requirements. Environmental and Experimental Botany 64: 162-170.

Ang, L., D. Guo, Z. Wang, and H. Liu. 2009. Nitrogen and phosphorus allocation in leaves, twigs, and fine roots across 49 temperate, subtropical and tropical tree species: a hierarchical pattern. Functional Ecology 24: 1-9.

Anikwe, M.A., C.N. Mbah, P.I. Ezeaku, and V.N. Onyia. 2007. Tillage and plastic mulch effects on soil properties and growth and yield of cocoyam (Colocasia esculenta) on an ultisol in southeast- ern Nigeria. Soil and Tillage Research 93: 264 272.

Ayala, M., and G. Lang. 2004. C-Partitioning in Sweet Cherry (Prunus avium L) during early spring. Hortscience 39: 887-887.

Baghour, M., L. Ragala, D.A. Moreno, G. Villora, J. Hernández, N. Castilla, and L. Romero. 2003. Effect of root zone temperature on accumulation of molybdenum and nitrogen metabolism in potato plants. Journal of Plant Nutrition 26: 443-461.

Baldi, E., C. Wells, and B. Marangoni. 2010. Nitrogen absorption and respiration in white and brown peach roots. Journal of Plant Nutrition. 33: 461-469.

Black, B.L., D. Drost, T. Lindstrom, J. Reeve, J.D. Gunnell, and G.L. Reighard. 2010. A comparison of root distribution patterns among Prunus rootstocks. Journal of the American Pomological Society 64: 52-62.

Böhm, W. 1979. Methods of studying root systems. Springer-Verlag, Berlin. 188 pp.

Bonomelli, C., C. Bonilla, and F. Nuñez. 2009. Soil 
temperature effect on root growth of cherry trees. (Prunus avium L.). VI International Cherry Symposium (ISHS-Pontificia Universidad Católica de Chile). November 15-19, 2009. Reñaca, Viña del Mar, Chile (Abstract).

CIREN. 1996. Estudio Agrológico VI región. Descripción de suelos, materiales y símbolos. Centro de Información de Recursos Naturales, Ministerio de Agricultura (CIREN), Gobierno de Chile, Santiago, Chile. 570 pp.

Comas, L.H., D. M. Eissenstat, and A.N. Lakso. 2000. Assessing root death and root system dynamics in a study of grape canopy pruning. New Phytologist 147: 171-178.

Comas, L., T. Bouma, and D. Eissenstat. 2002. Linking root traits to potential growth rate in six temperate tree species. Oecologia 132: 34-43.

Day, K., G. Lopez, and T. DeJong. 2008. Using growing degree hours accumulated thirty days after bloom to predict peach and nectarine harvest date. Acta Horticulturae (ISHS) 803: 163 166.

Díaz-Pérez, J. 2009. Root zone temperature, plant growth and yield of broccoli [Brassica oleracea (Plenck) var. italica] as affected by plastic film mulches. Scientia Horticulturae 123: 156-163.

Flore, J.A., and D.R. Layne. 1999. Photoassimilate production and distribution in cherry. HortScience 34: 1015-1019.

Futsaether, C.M., and U. Oxaal. 2002. A growth chamber for idealized studies of seedling root growth dynamics and structure. Plant and Soil 246: 221-230.

Gastó, J., L. Vieli, and C. Gálvez. 2008. Estudio ecológico de plantaciones de Quillay (Quillaja saponaria): condiciones de sitio, ordenación y restauración. Ediciones Universidad Católica de Chile. Santiago, Chile. 132 pp.

Gil, G. 1999. Fruticultura: El potencial productivo. Crecimiento vegetativo y diseño de huertos y viñedos. Segunda edición. Ediciones Universidad Católica de Chile, Santiago, Chile. 600 pp.

Gratacós, E., A. Cortés, and B.M. Kulczewski. 2008. Rootstock effects on two sweet cherry cultivars in Central Chile. Acta Horticulturae 795:227-238.
Grossman, Y., and T. Dejong. 1995. Maximum vegetative growth potential and seasonal patterns of resource dynamics during peach growth. Annals of Botany 76: 473-482.

Honorato, R., H. Silva, and C. Bonomelli. 1990. Edaphic relationships and vineyard productivity in the Metropolitan Region. Ciencia e Investigación Agraria 17: 133-143.

Ibarra, L., A. Zermeño, J. Murguía, R. Quezada, and M. Rosa. 2008. Photosynthesis, soil temperature and yield of cucumber as affected by colored plastic mulch. Acta Agriculture Scandinavia. Sect. B, Soil and Plant Science 58: 372-378.

Jiménez, S., A. Garín, E. Albás, J. Betrán, Y. Gogorcena, and M. Moreno. 2004. Effect of several rootstocks on the fruit quality of 'Sunburst' sweet cherry. Acta Horticulturae 658: 353-358.

Jiménez, S., J. Pinochet, Y. Gogorcena, E. Betrán, and M. Moreno. 2007. Influence of different vigour cherry rootstocks on leaves and shoots mineral composition. Scientia Horticulturae 112:73-79.

Lamont, J. W. 2005. Plastic: modifying the microclimate for the production of vegetable crops. Horticultural Technology 15: 477-481.

Larsson, L., and P. Jensen. 1996. Effects of mulching on the root and shoot growth of young black currant bushes. Acta Agriculture Scandinavia.Sect. B, Soil and Plant Science 46: 197-207.

Moreno, M.A., R. Adrada, J. Aparicio and J.A. Betrán. 2001. Performance of 'Sunburst' sweet cherry grafted on different rootstocks. Journal of Horticultural Science and Biotechnology 76: 167-173.

Neilsen, G., and F. Kappel. 1996. "Bing" sweet cherry leaf nutrition is affected by rootstock. Hortscience 31: 1169-1172.

Neumann, G., T.S. George, and C. Plassard. 2009. Strategies and methods for studying the rhizosphere-the plant science toolbox. Plant Soil 321:431-456.

Sitarek, M., L. Sitarek, M., and S. Paszt. 2005. Studies on the root systems of sweet cherry trees grafted on different rootstocks-preliminary results. Journal of Fruit and Ornamental Plant Research 13:25-37. 
Sotomayor, H., C. Bonomelli, and C. Bonilla. 2009.

Diseño de un rizotrón para el estudio y seguimiento fotográfico de raíces en huertos frutales. Revista Aconex (Chile) 104: 12-18.

Steel, R., J. Torrie, and D. Dickey. 1997. Principles and procedures of statistical biometrical approach. Third edition. Mc Grw-Hill, Inc, New York. 481 pp.

Volder, A., R. Smart, A. Bloom, and D. Eissenstat. 2005. Rapid decline in nitrate uptake and res- piration with age in fine lateral roots of grape: implications for root efficiency and competitive effectiveness. New Phytologist. 165: 493-501.

Wells, C.E., and D. M. Eissenstat. 2001. Marked Differences in Survivorship among apple roots of different diameter. Ecology 82: 882-892.

Wells, C. E., and D. M. Eissenstat. 2003. Beyond the roots of young seedlings: the influence of age and order on fine root physiology. Journal Plant Growth Regulator 21: 324-334. 